\title{
Barriers in the pelagic: population structuring of Calanus helgolandicus and C. euxinus in European waters
}

\author{
Lidia Yebra $^{1,4, *}$, Delphine Bonnet ${ }^{1,2}$, Roger P. Harris ${ }^{1}$, Penelope K. Lindeque ${ }^{1}$, \\ Katja T. C. A. Peijnenburg ${ }^{3}$ \\ ${ }^{1}$ Plymouth Marine Laboratory, Prospect Place, Plymouth PL1 3DH, UK \\ ${ }^{2}$ Laboratoire Ecosystèmes lagunaires, UMR 5119, Université Montpellier II, Place Eugène Bataillon, Case Courrier 093 , \\ 34095 Montpellier Cedex 5, France \\ ${ }^{3}$ Institute for Biodiversity and Ecosystem Dynamics, University of Amsterdam, PO Box 94240, 1090 GE Amsterdam, \\ The Netherlands \\ ${ }^{4}$ Present address: Instituto Español de Oceanografía, Centro Oceanográfico de Málaga, Apdo. 285, 29640 Fuengirola, \\ Málaga, Spain
}

\begin{abstract}
Molecular studies of marine plankton have shown that ecological and/or environmental barriers play an important role in separating populations. Calanoid copepods are central in marine ecosystems, and dramatic biogeographical shifts in copepod assemblages associated with recent climate warming have been reported. We examined spatial population structuring in European waters of the Atlantic Ocean and Mediterranean Sea of Calanus helgolandicus and its sister species, C. euxinus, from the Black Sea based on genetic and morphometric characters. The aims were to identify barriers to dispersal, relate these to hydrographic characteristics and infer historical patterns of distribution and demography. We analysed a $408 \mathrm{bp}$ fragment of the mitochondrial 16S gene (316 individuals), prosome to urosome length relationships (212 individuals) and sea surface temperatures obtained from 19 European sites. Estimates of genetic differentiation between samples and hierarchical analyses of molecular variance indicated strong spatial population structuring between, as well as within, basins. We identified 7 phylogeographic groups: Fjords, Oceanic inflow, NE Atlantic/Tyrrhenian, Adriatic, Mljet Island, Aegean, and Black Sea, which explained 39.7\% of the total genetic variation. Based on genetic data, C. euxinus is considered to be a differentiated population within the $C$. helgolandicus distribution range because the most important genetic barrier separates western and eastern Mediterranean populations. Morphometric barriers largely reflect sea surface temperature barriers and are not congruent with the main genetic barriers. Contrary to recent findings for $C$. finmarchicus, we conclude that $C$. helgolandicus/C. euxinus populations are not connected by high levels of dispersal and have been vulnerable to past climatic changes.
\end{abstract}

KEY WORDS: Calanus helgolandicus $\cdot$ Calanus euxinus $\cdot 16 \mathrm{~S}$ rDNA $\cdot$ Mediterranean Sea $\cdot$ North Atlantic Ocean · Black Sea

\section{INTRODUCTION}

Little is known about the origin and maintenance of pelagic (open ocean) biodiversity. Understanding evolutionary processes in the pelagic realm is particularly difficult because barriers to gene flow are often obscure and pelagic taxa typically lack fossil records (Angel
1993, Norris 2000). Molecular markers can provide important insights into fundamental questions, such as those raised by Fleminger \& Hulsemann (1987, p. 46): 'Does local patchiness in zooplankton concurring with environmental selection pressures lead to adaptive consequences of evolutionary significance? And more generally, at what geographical scale do we find evi- 
dence of genetic change in conspecific planktonic populations, and what is the significance of such changes relative to the breadth and width of pelagic ecosystems?' Molecular studies of marine plankton have challenged the long standing view of widespread panmictic populations that result in relatively few and slowly evolving species by showing that ecological and/or environmental barriers play an important role in separating populations (e.g. De Vargas et al. 1999, Bucklin et al. 2000a, Goetze 2003, Peijnenburg et al. 2004).

Connectivity (the extent to which populations are connected through exchange of individuals) among populations can be affected by a range of factors, the most obvious of which are physical barriers to dispersal. Biological factors may also play an important role in determining population structuring (e.g. Marshall et al. 2010), but some counterintuitive results have been reported. For instance, Patarnello et al. (2007) investigated the significance of the Atlantic-Mediterranean transition zone across physical barriers such as the Gibraltar Strait and Almeria-Oran Front (AOF) by reviewing 75 genetic studies of marine taxa ranging from plants to marine mammals. They found no obvious relationship between either dispersal ability or life history traits and genetic structuring, and reported patterns of no differentiation (32 studies), weak differentiation (2 studies) and strong differentiation (41 studies) between Atlantic and Mediterranean populations. Similarly, Galarza et al. (2009) who compared gene flow patterns of 7 littoral fish species across 2 oceanographic fronts in the western Mediterranean (the AOF and the Balearic Front) reported diverse patterns for different species and found no correlation between dispersal potential or any life history trait and degree of genetic structuring. Clearly, determining the relative influence of physical and biotic factors on genetic connectivity in marine populations is not a trivial task.

Members of the genus Calanus are among the largest copepods and play critical roles in marine ecosystems as grazers of microplankton and as a major food source for larvae, juveniles and adults of commercially important fishes (e.g. Meyer-Harms et al. 1999, Gislason \& Astthorsson 2002). Additional interest in Calanus populations has come from analysis of long time series such as the Continuous Plankon Recorder survey (CPR) that has shown dramatic biogeographical shifts in calanoid copepod assemblages (Beaugrand et al. 2002, Hays et al. 2005). For example, Beaugrand et al. (2002) showed that in the North Sea, species associated with warm waters such as $C$. helgolandicus have expanded north by $10^{\circ}$ of latitude during the last $50 \mathrm{yr}$.

This study focuses on Calanus helgolandicus (Claus 1863) and its sister species in the Black Sea, C. euxinus (Hulsemann 1991). The distribution of these species covers a wide range of habitats from open ocean to coastal environments (Bonnet et al. 2005 and references therein). C. helgolandicus occurs from neritic waters off eastern North America across the temperate North Atlantic Ocean to the northern Mediterranean Sea. In the western Mediterranean Sea its abundance is generally low and it appears mainly during winter months, residing at greater depths during the remainder of the year (Andersen et al. 2001). The species dominates the northern shelf and slope regions, but has also been reported on the southern coasts (off Tunisia) probably transported with Atlantic waters through the Strait of Gibraltar. In the eastern Mediterranean, the species is common in the Adriatic and Ionian seas, but it is only present seasonally and in small numbers in the Aegean Sea. The species has also been reported in the Levantine basin, but seasonal reproduction in this basin remains uncertain. In the Atlantic Ocean, C. helgolandicus diapauses at great depths $(\sim 1000 \mathrm{~m})$ during the winter months (Williams \& Conway 1988, Bagoeien et al. 2001), whilst in the Mediterranean Sea, the species probably 'oversummers' at great depths $(>1000 \mathrm{~m})$ to avoid high temperatures (Scotto di Carlo \& Ianora 1983, Weikert et al. 2001). C. helgolandicus and $C$. euxinus are considered cold water or 'boreal' elements in the Mediterranean and Black Sea faunas, which colonised the Mediterranean basin from the Atlantic during glacial periods of the Pleistocene (Angel 1979, Furnestin 1979, Bianchi \& Morri 2000). C. euxinus is endemic to the Black Sea and was identified as a different species based on differences in prosome to urosome length relationships and integumental pore signatures (Fleminger \& Hulsemann 1987). It is worth noting that hydrographic exchange and environmental conditions differ considerably across the distribution of these species and this potentially allows for the adaptive evolution of populations.

The first genetic studies of Calanus helgolandicus focussed on molecular identification of co-occurring Calanus species in the North Atlantic Ocean (Bucklin et al. 1999, Lindeque et al. 1999). Two more recent phylogeographic analyses of $C$. helgolandicus and C. euxinus (Papadopoulos et al. 2005, Unal et al. 2006) reported significant population structuring between Atlantic, Mediterranean and Black Sea populations but could not resolve population structuring within basins because of limited sampling. Based on coalescent analyses of mitochondrial DNA (mtDNA) sequences of cytochrome oxidase I (COI), Papadopoulos et al. (2005) concluded that divergences between NE Atlantic, Mediterranean, and Black Sea populations dated back to the middle Pleistocene. Similar results have been reported for populations of blue mussel Mytilus galloprovincialis (Ladoukakis et al. 2002), a planktonic chaetognath, Sagitta setosa (Peijnenburg et 
al. 2004), common shrimp Crangon crangon (Luttikhuizen et al. 2008), and European anchovy Engraulis encrasicolus (Magoulas et al. 2006). Papadopoulos et al. (2005) and Unal et al. (2006) both suggested that none of the Calanus populations were singled out based on genetic data and therefore called the species status of $C$. euxinus into question. In the present study, we consider C. euxinus as the Black Sea population of C. helgolandicus, which may or may not have diverged enough to represent a different biological species. To test this, crossing experiments would be necessary, which have not yet been carried out.

The present study has built on the network of sampling stations established by Bonnet et al. (2005) and uses a more intense sampling scheme compared with previous studies, both in terms of geographic and temporal coverage, and numbers of individuals analysed. We collected sequence data for a portion of the mitochondrial 16S gene together with morphometric measurements (prosome and urosome length) and environmental data obtained from the same sites. The aims of this study are to (1) assess spatial population structur- ing of Calanus helgolandicus and C. euxinus based on genetic and morphometric characters, (2) reveal barriers to dispersal and relate these to hydrographic characteristics and (3) infer historical patterns of distribution and demography to provide insights into previous responses of these species to climatic fluctuations in the Pleistocene.

\section{MATERIALS AND METHODS}

Sampling. Copepods were collected from 19 sites throughout Europe encompassing the NE Atlantic Ocean, Mediterranean Sea and Black Sea at different times of the year between 1999 and 2006 (Table 1, Fig. 1A). Female Calanus helgolandicus (C. euxinus in the Black Sea) were collected by net tows and preserved in $95 \%$ ethanol.

Molecular analysis. A $408 \mathrm{bp}$ fragment of the $16 \mathrm{~S}$ mitochondrial gene was amplified for 316 individual copepods (between 4 and 59 copepods per site, Table 1). Each copepod was removed from ethanol and re-

Table 1. Calanus helgolandicus and C. euxinus. Sampling information including sampling site, location, date, collector's name, June and December mean SST $\left({ }^{\circ} \mathrm{C}\right)$, and number of copepods sequenced (n) and measured (N). Estimates of genetic diversity based on 16S mitochondrial DNA sequences are given per sample as nucleotide diversity, $\pi\left(\times 10^{-3}\right)$, and haplotype diversity $(h)$

\begin{tabular}{|c|c|c|c|c|c|c|c|c|c|c|}
\hline Site & Latitude & Longitude & Sampling date & Collector & $\begin{array}{l}\text { June } \\
\text { SST }\end{array}$ & $\begin{array}{l}\text { December } \\
\text { SST }\end{array}$ & $\mathrm{n}$ & $\mathrm{N}$ & $\begin{array}{c}\pi \\
\left(\times 10^{-3}\right)\end{array}$ & $h$ \\
\hline Raunefjord & $60^{\circ} 16.0^{\prime} \mathrm{N}$ & $05^{\circ} 14.0^{\prime} \mathrm{E}$ & June 2006 & J. C. Nejstgaard & 11.2 & 8.1 & 19 & 1 & 1.6 & 0.56 \\
\hline Faroe & $60^{\circ} 28.0^{\prime} \mathrm{N}$ & $09^{\circ} 23.0^{\prime} \mathrm{W}$ & July 2006 & E. Gaard & 10.1 & 8.3 & 16 & 2 & 6.0 & 0.54 \\
\hline Gijón & $43^{\circ} 34.8^{\prime} \mathrm{N}$ & $05^{\circ} 36.5^{\prime} \mathrm{W}$ & May to Sept 2005 & J. Cabal & 16.1 & 13.3 & 22 & 15 & 5.5 & 0.71 \\
\hline Dogger Bank & $\begin{array}{l}55^{\circ} \mathrm{N} \& \\
56.4^{\circ} \mathrm{N}\end{array}$ & $\begin{array}{l}03^{\circ} \mathrm{E} \& \\
05.39^{\circ} \mathrm{E}\end{array}$ & August 2005 & S. H. Jónasdóttir & 12.2 & 8.6 & 23 & 14 & 2.3 & 0.46 \\
\hline Helgoland & $54^{\circ} 11.2^{\prime} \mathrm{N}$ & $07^{\circ} 54.0^{\prime} \mathrm{W}$ & August 2005 & R. Diekman & 12.7 & 7.3 & 14 & 8 & 2.1 & 0.27 \\
\hline Plymouth & $50^{\circ} 15.0^{\prime} \mathrm{N}$ & $04^{\circ} 13.0^{\prime} \mathrm{W}$ & $\begin{array}{l}\text { June } 2005 \text { \& } \\
\text { January } 2006\end{array}$ & $\begin{array}{l}\text { D. Bonnet, } \\
\text { L. Yebra }\end{array}$ & 14.0 & 11.6 & 59 & 14 & 2.0 & 0.42 \\
\hline Trieste & $45^{\circ} 42.0^{\prime} \mathrm{N}$ & $13^{\circ} 43.0^{\prime} \mathrm{E}$ & January 2006 & V. Tirelli & 21.5 & 12.1 & 14 & 20 & 4.0 & 0.82 \\
\hline S Adriatic & $42^{\circ} 37.0^{\prime} \mathrm{N}$ & $18^{\circ} 06.0^{\prime} \mathrm{E}$ & June 2005 & D. Lučić & 20.1 & 15.9 & 11 & 3 & 3.0 & 0.76 \\
\hline Ionian Stns $157 \& 73$ & $\begin{array}{l}38^{\circ} 11.6^{\prime} \mathrm{N} \& \\
38^{\circ} 09.7^{\prime} \mathrm{N}\end{array}$ & $\begin{array}{l}20^{\circ} 56.2^{\prime} \text { E \& } \\
22^{\circ} 53.5^{\prime} \text { E }\end{array}$ & June 1999 & A. Ramfos & 23.5 & 18.2 & 6 & 2 & 4.4 & 0.80 \\
\hline Mljet & $42^{\circ} 46.0^{\prime} \mathrm{N}$ & $17^{\circ} 22.0^{\prime} \mathrm{E}$ & June 2005 & D. Lučić & 21.7 & 12.9 & 15 & 20 & 5.7 & 0.79 \\
\hline Aegean Stns 12 \& 24 & $\begin{array}{l}39^{\circ} 06.3^{\prime} \mathrm{N} \& \\
38^{\circ} 45.6^{\prime} \mathrm{N}\end{array}$ & $\begin{array}{l}23^{\circ} 19.3^{\prime} \text { E \& } \\
23^{\circ} 11.1^{\prime} \mathrm{E}\end{array}$ & May 1999 & A. Ramfos & 20.2 & 16.2 & 9 & 20 & 10.6 & 0.94 \\
\hline Black Sea Stns i \& vi & $\begin{array}{l}43^{\circ} 09.8^{\prime} \mathrm{N} \& \\
44^{\circ} 09.9^{\prime} \mathrm{N}\end{array}$ & $\begin{array}{l}28^{\circ} 50.0^{\prime} \text { E \& } \\
29^{\circ} 30.1^{\prime} \mathrm{E}\end{array}$ & June 2006 & L. Kamburska & 19.0 & 11.0 & 17 & 8 & 1.4 & 0.33 \\
\hline
\end{tabular}




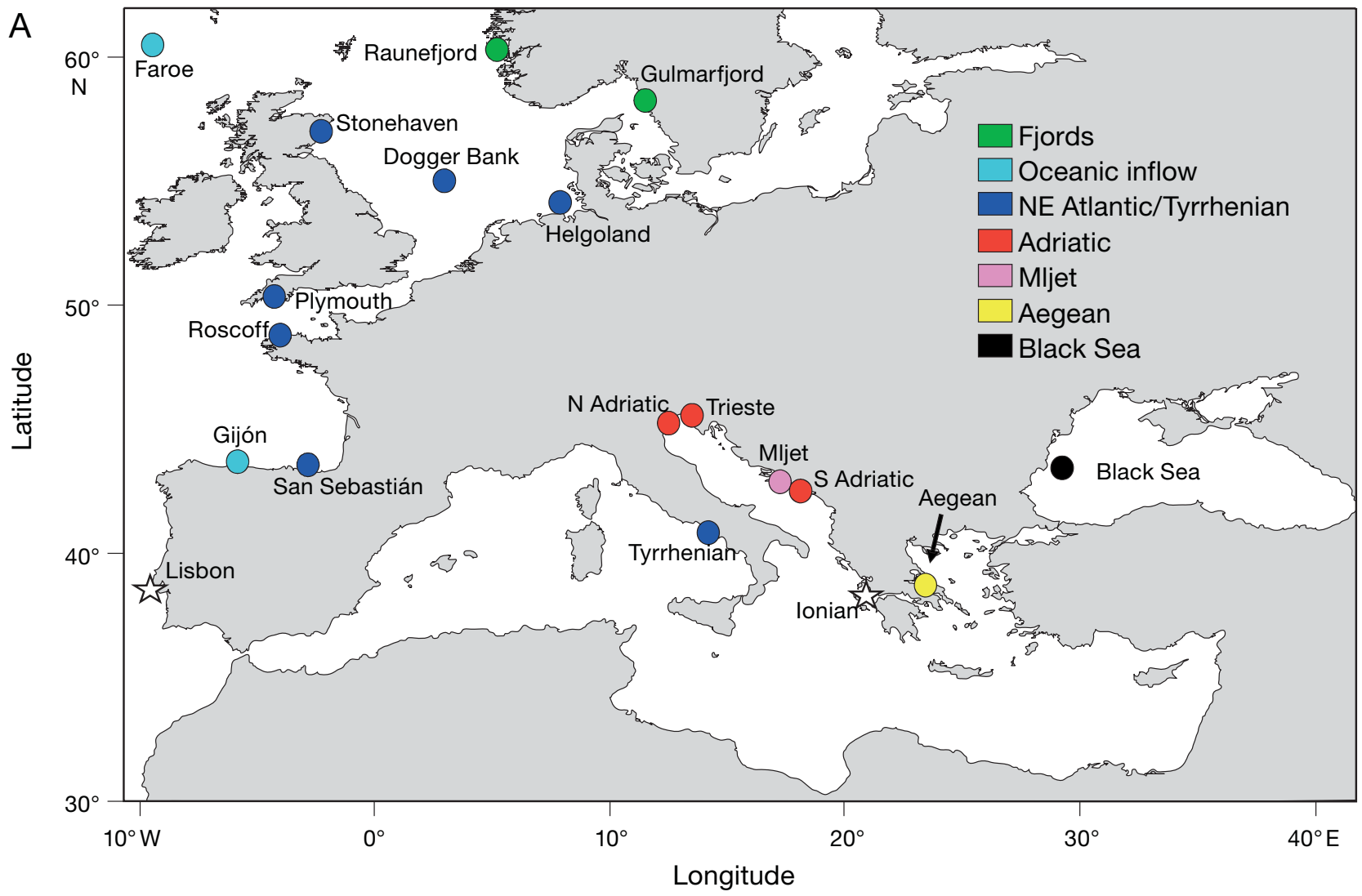

B

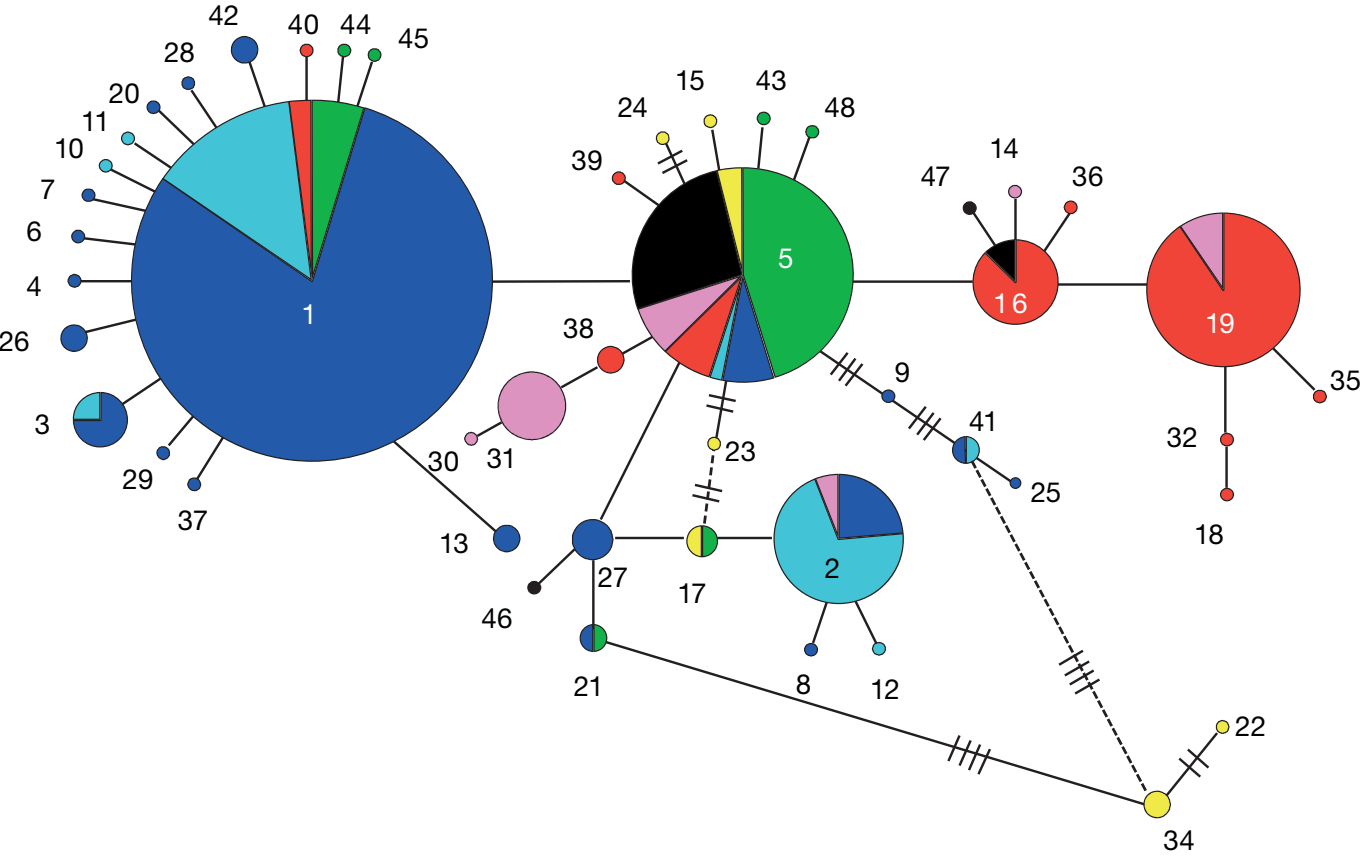

Fig. 1. Calanus helgolandicus and C. euxinus. (A) Location of sampling stations. Different colours indicate 7 phylogeographic groups: Fjords, Oceanic inflow, NE Atlantic/ Tyrrhenian, Adriatic, Mljet Island, Aegean Sea, and Black Sea. The Lisbon and Ionian samples could not be assigned to a phylogeographic group because of low sample sizes and are shown by star symbols (see text). (B) Minimum spanning network showing evolutionary relationships among 47 mitochondrial 16S haplotypes of C. helgolandicus (NE Atlantic and Mediterranean) and C. euxinus (Black Sea). Colours correspond to phylogeographic groups shown in (A). Each circle represents a single haplotype and its diameter is proportional to the number of individuals carrying that haplotype, with the smallest circles representing 1 individual. Each line in the network represents a single mutational change; dashes on lines connecting haplotypes represent number of base substitutions $>1$ between haplotypes 
hydrated in $0.5 \mathrm{ml}$ Milli-Q water overnight at room temperature. After rehydration, each individual was placed into a $0.5 \mathrm{ml}$ microcentrifuge tube containing $32 \mu \mathrm{l}$ Milli-Q water and $5 \mu \mathrm{l}$ 10× JumpStart Taq DNA polymerase buffer (Sigma Aldrich). Copepods were homogenised with a pellet pestle motor (Anachem) and incubated overnight at $4^{\circ} \mathrm{C}$. After incubation, $13.5 \mu \mathrm{l}$ master mix [ $5 \mu \mathrm{l}$ of $2 \mathrm{mM}$ deoxynucleoside triphosphate (dNTP) (Promega), $4 \mu \mathrm{l}$ of each primer $(10 \mu \mathrm{M}): 16 \mathrm{SAR}$ (5'-CGC CTG TTT AAC AAA AAC AT-3', Palumbi \& Benzie 1991) and 16SB2R (5'-ATT CAA CAT CGA GGT CAC AAA C-3', Lindeque et al. 1999) and 0.5 l Jumpstart Taq DNA polymerase (Sigma Aldrich)] were added to each tube. Amplification was carried out in a thermocycler (GeneAmp PCR system 9700, Applied Biosystems or PTC-100, MJ Research) following the cycling parameters described in Lindeque et al. (1999). Aliquots (5 $\mu \mathrm{l})$ of the amplification reactions were checked by agarose gel electrophoresis. PCR products $(2.5 \mu \mathrm{l})$ were cleaned before sequencing by adding $1 \mu \mathrm{l}$ ExoSapIT and incubating at $37^{\circ} \mathrm{C}$ for $15 \mathrm{~min}$ and at $80^{\circ} \mathrm{C}$ for $15 \mathrm{~min}$. Cleaned amplification products were sequenced in both directions with a cycle sequencing kit (BigDye Terminator v. 3.1, Applera) on a gene sequencer (ABI 3100, Applied Biosystems).

DNA sequence analysis. All polymorphic sites were manually double-checked and resolved by comparing forward and reverse chromatographs. Sequences were unambiguously aligned with the DnaSP program (Rozas et al. 2003). We estimated genetic variation per sampling site as haplotype diversity, $h$, (Nei 1987) and nucleotide diversity, $\pi$ (Tajima 1983, Nei 1987) in Arlequin v. 3.5 (Excoffier et al. 2005). A minimum spanning network of $16 \mathrm{~S}$ haplotypes was also constructed. Since our data set did not show any signs of sequence saturation, simple pairwise differences between haplotypes were used as a measure of genetic distance. To test for spatial genetic structuring of samples, we used 2 approaches. (1) We calculated pairwise $\Phi_{\text {ST }}$ values between sampling sites (tested by 10000 permutations as implemented in Arlequin). (2) We performed hierarchical analyses of molecular variance (AMOVA) in Arlequin to examine the partitioning of the total variance between various groups of samples. Using these approaches, we identified 7 phylogeographic groups. Remaining analyses were carried out on pooled samples per phylogeographic group. Demographic history was examined in terms of mismatch distributions, i.e. the distribution of the observed number of differences among all pairs of haplotypes in Arlequin. Population expansions produce a wave in the mismatch distribution creating a unimodal distribution. L-shaped mismatch distributions with a high probability of identical sequences are expected for populations that have recently undergone a population or genetic bottle- neck. By contrast, multi-modal distributions are expected for samples drawn from populations with constant population sizes (Rogers \& Harpending 1992). To test for deviations of the neutral model (selective neutrality and population equilibrium) we computed Tajima's D (Tajima 1989) and Fu's $F_{s}$ (Fu 1997) test statistics. The significance of empirical values of $D$ and $F_{s}$ were tested by comparison of observed values to null distributions generated by 10000 permutations in Arlequin. Uncorrected genetic distances ( $p$-distances) between all haplotypes were calculated in PAUP v. 4.0b10 (Swofford 1998).

Morphometric analysis. A total of 212 undamaged adult Calanus females were selected for morphological analysis from the same samples that were used in genetic analyses (but different individuals). Unfortunately, some samples (e.g. Tyrrhenian Sea) contained no or few adult females (Table 1). Prosome and urosome lengths were measured under a binocular microscope with an eye-piece graticule. Since size is known to vary according to temperature and food conditions, we focussed on prosome and urosome length relationships as suggested by Fleminger \& Hulsemann (1987). The significance of the Pearson coefficients of the linear regressions was tested to determine the correlation between prosome and urosome lengths within each group (Student's $t$-test). The slopes and the origin ordinates of the linear regressions were compared between the groups by means of an analysis of covariance.

Geographic analysis. To visualise where areas of abrupt change (barriers) in the genetic or morphological composition of samples were geographically located and to possibly link these with environmental parameters, we used Monmonnier's maximum difference algorithm as implemented in Barrier v. 2.2 (Manni et al. 2004 and references therein). This algorithm finds the edges associated with the highest rate of change in a given distance measure, which can be genetic, morphological or environmental (we used sea surface temperature, SST). The algorithm is applied to a geometric network that connects all samples using Delaunay triangulation followed by Voronoi tessellation (further details in Manni et al. 2004). The first boundary is traced perpendicular to the edges of the triangulation, starting from the edge for which the distance value is maximum and proceeding across adjacent edges until the barrier has reached the limits of the triangulation or closes on itself. The next barriers are constructed one after another in a hierarchical order. We chose to present 6 genetic barriers because these barriers coincided with significant $\Phi_{\mathrm{ST}}$ values between samples. Distance matrices (Euclidean distance) of prosome/urosome ratio and SST (composite of June and December averages, Table 1) were computed with PRIMER 6 software (Clarke \& Warwick 1994). 


\section{RESULTS}

\section{Genetic diversity and population structuring}

We found 48 different haplotypes in a total data set of 316 mitochondrial 16S sequences collected from samples across the distributional range of Calanus helgolandicus and C. euxinus (Table 1, Genbank accession numbers FJ861604 to FJ861653). Sixteen of these haplotypes were shared between individuals and 32 represented unique haplotypes, resulting in a highly skewed haplotype distribution (Table A1 in the Appendix). Haplotype diversities ranged from 0.24 (San Sebastián) to 0.94 (Aegean Sea) and nucleotide diversities ranged from 0.0009 (San Sebastián) to 0.0106 (Aegean Sea), excluding the Lisbon sample because only 4 individuals were sampled, which had identical haplotypes (Table 1).

Evolutionary relationships among haplotypes are shown in Fig. 1B as a minimum spanning network with the main phylogeographic groups indicated in different colours as described in the next paragraph. Two samples could not be confidently assigned to a phylogeographic group because of low sample sizes (Lisbon and Ionian Sea) and were removed from the network. Two of 5 alternative connections were resolved based on criteria derived from coalescent theory (Pfenninger \& Posada 2002). We kept 2 alternative connections (dotted lines) resulting in loops connecting haplotypes 17 (H17) and H27 and related haplotypes to the 2 most common haplotypes $\mathrm{H} 1$ and H5. A third alternative connection was kept linking the highly divergent haplotype H34 to H41. Haplotype 1 (H1) is the most abundant haplotype in the NE Atlantic Ocean and Tyrrhenian Sea and is surrounded by several closely related unique or low frequency haplotypes resulting in a starlike structure. H5 is the central haplotype in the network and found in all geographic areas making it the most likely ancestral haplotype. It is also the most abundant haplotype in the Fjords and Black Sea samples. Haplotype 2 represents a divergent lineage (3 and 4 mutational steps away from $\mathrm{H} 5$ and $\mathrm{H} 1$, respectively) and is most commonly found in the more western Atlantic samples (Faroe Islands and Gijón) termed 'Oceanic inflow' group. Other area-specific haplotypes include $\mathrm{H} 16$ and H19, which are most commonly found in the Adriatic Sea, H31, which is unique to the Mljet population, and H34, which is on a long branch and unique to the Aegean Sea.

Estimates of genetic differentiation between samples (pairwise $\Phi_{\mathrm{ST}}$, Table 2) and hierarchical AMOVA (Table 3) indicated strong spatial structuring between as well as within basins. Of the total mitochondrial variance, $28.1 \%$ was due to genetic differentiation among 4 basins (NE Atlantic, W and E Mediterranean, and Black Sea; $\mathrm{p}<0.001$ ) and $13.6 \%$ and $58.3 \%$ were due to variances among samples within basins and within samples, respectively (Table 3). Interestingly, the Tyrrhenian sample (located in the W Mediterranean basin) did not significantly differ from NE Atlantic samples but did show significant differentiation from all samples located in the E Mediterranean basin $\left(\Phi_{\mathrm{ST}}\right.$ between 0.236 and 0.580$)$. Within the NE Atlantic, the 2 fjord samples were significantly differentiated from all other samples $\left(\Phi_{\mathrm{ST}}\right.$ between 0.171 and 0.401 ) but not from each other, and the Faroe and Gijón samples were marginally differentiated from other Atlantic samples as well $\left(\Phi_{\text {Sт }}\right.$ between 0.106 and 0.223). The Lisbon sample was neither significantly differentiated from Faroe and Gijón nor from other NE Atlantic samples. Within the E Mediterranean basin, N Adriatic and S Adriatic populations were not genetically differentiated from each other $\left(\Phi_{\mathrm{ST}}\right.$ ranging from negative values to 0.031). However, the populations from the marine lake of Mljet Island and the Aegean Sea were significantly differentiated from the Adriatic samples and from each other $\left(\Phi_{\mathrm{ST}}\right.$ between 0.209 and 0.368). The Ionian sample did not significantly differ from any of the E Mediterranean samples, probably because of low sample size. We obtained a total of 7 phylogeographic groups - Fjords, Oceanic Inflow, NE Atlantic/Tyrrhenian, Adriatic, Mljet, Aegean, and Black Sea - that explained $39.7 \%$ of the total genetic variation ( $p<0.001$, Table 3$)$. Average genetic distance within phylogeographic groups ranged from $0.14 \%$ in the Black Sea to $1.06 \%$ in the Aegean Sea, and between phylogeographic groups ranged from 0.20 between Fjords and Black Sea to $1.01 \%$ between Mljet and Aegean Sea (Table A2). Average genetic distance between Calanus helgolandicus and C. euxinus sequences was $0.39 \%$.

\section{Demographic history and neutrality}

Mismatch distributions together with the results of neutrality tests clearly indicated different genetic signatures for the 7 phylogeographic groups (Fig. 2). Unimodal distributions of pairwise differences with the largest proportion in the ' 0 ' category (meaning that most haplotypes were the same) and significant deviations from neutrality were found for the Fjords and NE Atlantic/Tyrrhenian samples. Such genetic signatures are indicative of a recent population expansion, population bottleneck, founder event, selective sweep or a combination of these factors. By contrast, multimodal mismatch distributions and nonsignificant Tajima's D and Fu's $F_{\mathrm{s}}$ were found for Oceanic Inflow, Mljet and Aegean Sea samples, suggesting more stable population sizes and/or mixing of divergent haplotypes. The 


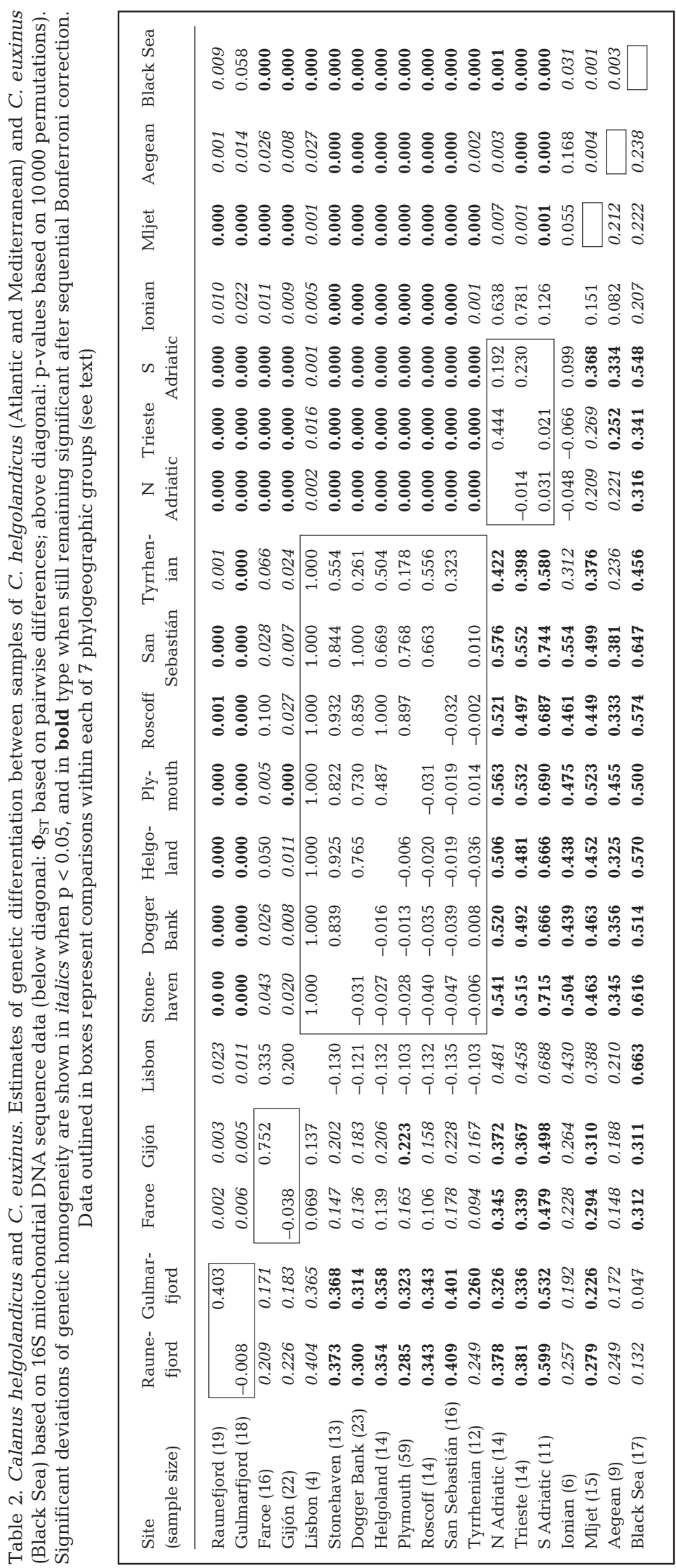

Adriatic Sea and Black Sea groups have an intermediate distribution with mixed results for the 2 neutrality tests. The Adriatic Sea has a unimodal mismatch distribution, suggestive of a population expansion, but with a higher mean number of pairwise differences than Fjords and NE Atlantic/Tyrrhenian samples, suggesting that the population expansion may be older (assuming equal mutation rates among samples). The Black Sea has a bimodal mismatch distribution but with a very high proportion of identical sequences.

\section{Morphometric diversity}

Individual prosome and urosome lengths showed geographic as well as seasonal variation. The largest individuals were collected in the Black Sea (June, $2.46 \pm 0.10 \mathrm{~mm}$, average $\pm \mathrm{SD}$ ) and Stonehaven (September, $2.55 \pm$ $0.08 \mathrm{~mm}$ ) and the smallest individuals were collected in the southern Adriatic Sea (June, $1.98 \pm 0.05 \mathrm{~mm}$ ) and Aegean Sea (May, $2.05 \pm$ $0.08 \mathrm{~mm}$ ) (data not shown). We also observed large seasonal variation in length from Plymouth samples collected every week in the year 2005 with the largest individuals collected in May $(2.61 \pm 0.12 \mathrm{~mm})$ and the smallest individuals collected in September (2.11 \pm $0.11 \mathrm{~mm}$, data not shown). For each of the 7 genetically differentiated groups, we found a significant positive relationship between prosome and urosome length except for the Black Sea. Since the slopes and origins did not significantly differ between groups $\left(F_{5,200}\right.$ $>-6.64, \mathrm{p}>0.05)$ we pooled all Atlantic and Mediterranean samples and obtained a single significant regression between prosome and urosome length $\left(\mathrm{r}^{2}=0.38, \mathrm{p}<0.001\right.$, Fig. 3). Also Black Sea samples (Calanus euxinus) have relatively longer prosomes compared with Atlantic and Mediterranean samples (Fig. 3). When prosome/urosome ratios are plotted against latitude we observed a weak gradient with decreasing ratios from north to south; however, this relationship was not significant (data not shown).

\section{Geographic barriers}

The strongest genetic barrier separates the E Mediterranean from the W Mediterranean and Atlantic samples (Fig. 4A). The second 
Table 3. Calanus helgolandicus and C. euxinus. Hierarchical analyses of mitochondrial 16S rDNA molecular variance (AMOVA) of $C$. helgolandicus and $C$. euxinus amongst (A) 4 European basins (NE Atlantic, W Mediterranean, E Mediterranean, Black Sea) and (B) amongst 7 phylogeographic groups (Fjords, Oceanic inflow, NE Atlantic/Tyrrhenian, Adriatic, Mljet, Aegean, and Black Sea). Lisbon and Ionian samples were removed because of low sample sizes (see text). Associated with each hierachical level are: percentage of total variance explained $(\%), \Phi$-statistics, df and associated significance levels: ${ }^{*} \mathrm{p}<0.05,{ }^{* *} \mathrm{p}<0.01,{ }^{* * *} \mathrm{p}<0.001$. ns: not significant

\begin{tabular}{|lcccc|}
\hline Source of variation & $\begin{array}{c}\% \text { of } \\
\text { variance }\end{array}$ & $\begin{array}{c}\text { Fixation } \\
\text { index }\end{array}$ & Significance & df \\
\hline (A) Four basins & & & & \\
Among basins (17 sites, 4 groups) & 28.1 & $\Phi_{\mathrm{CT}}=0.28$ & $* * *$ & 3 \\
Among populations within basins & 13.6 & $\Phi_{\mathrm{SC}}=0.19$ & ${ }^{* * *}$ & 13 \\
Among populations within total & 41.7 & $\Phi_{\mathrm{ST}}=0.42$ & $* *$ & 289 \\
Within populations & 58.3 & & & \\
& & & & \\
(B) 7 phylogeographic groups & & & & \\
Among groups (17 sites, 7 groups) & 39.7 & $\Phi_{\mathrm{CT}}=0.40$ & $* * *$ & 6 \\
Among populations within groups & -1.1 & $\Phi_{\mathrm{SC}}=-0.02$ & ${ }^{* * *}$ & 10 \\
Among populations within total & 38.6 & $\Phi_{\mathrm{ST}}=0.39$ & & 289 \\
Within populations & 61.4 & & & \\
\hline
\end{tabular}

and third genetic barriers separate peripheral marine habitats from other samples, namely the 2 fjords from NE Atlantic samples (barrier 2) and the marine lake (Mljet) from Adriatic samples (barrier 3). Barriers 4, 5 and 6 represent marginally significant differentiation $\left(\Phi_{\text {Sт }}\right.$ between 0.147 and 0.238 , Table 2) with barrier 4 separating the Black Sea from E Mediterranean samples and barriers 5 and 6 separating Oceanic Inflow samples (Faroe and Gijón) from other NE Atlantic samples. The strongest morphometric barriers are located in the $\mathrm{E}$ Mediterranean basin (Fig. 4B), with the first barrier separating Adriatic samples and the second barrier separating the Black Sea population (Calanus euxinus) from E Mediterranean samples. Morphometric barriers 3 and 4 probably represent
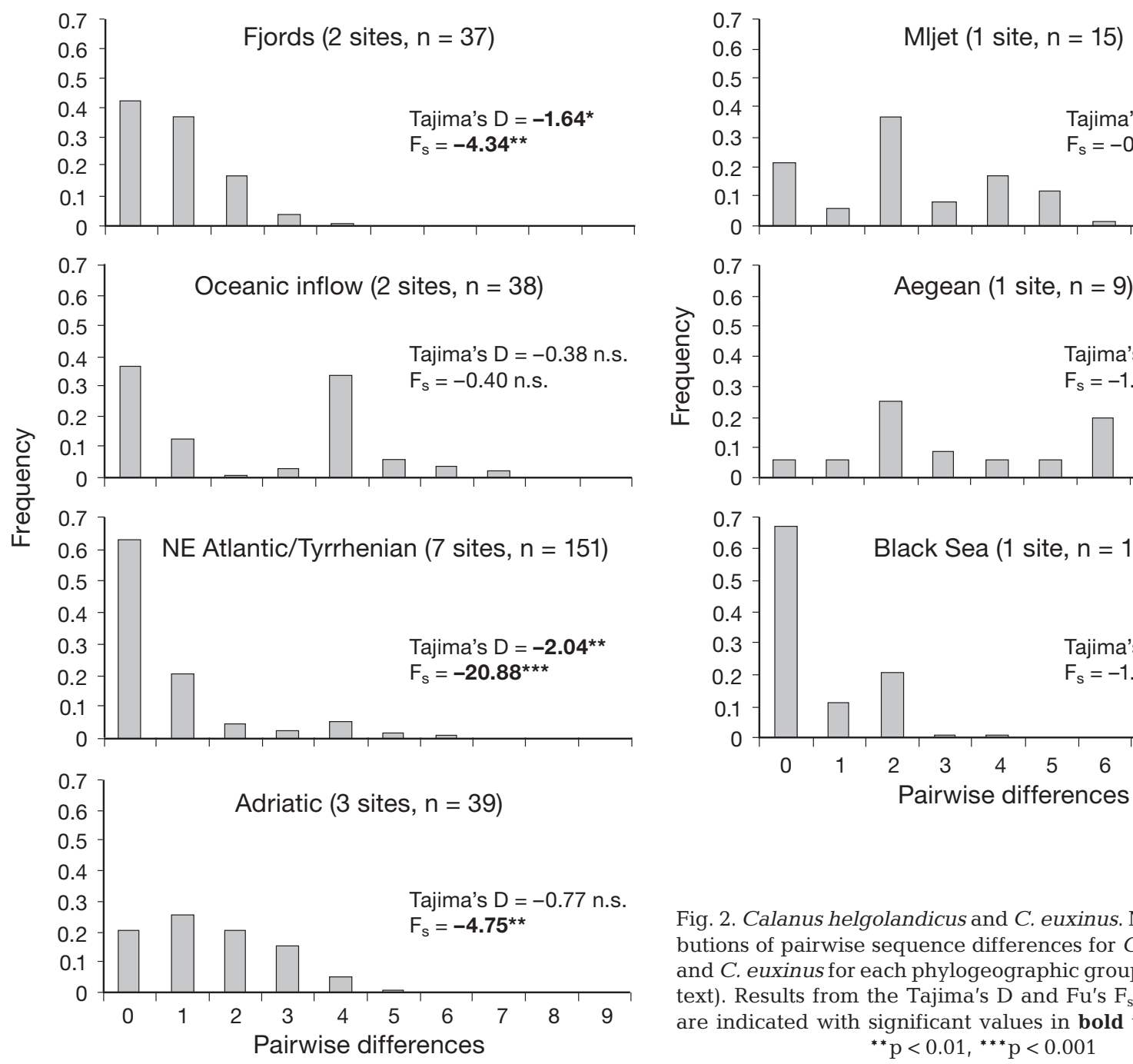

Tajima's $\mathrm{D}=-0.60$ n.s. $F_{\mathrm{s}}=-0.42$ n.s.
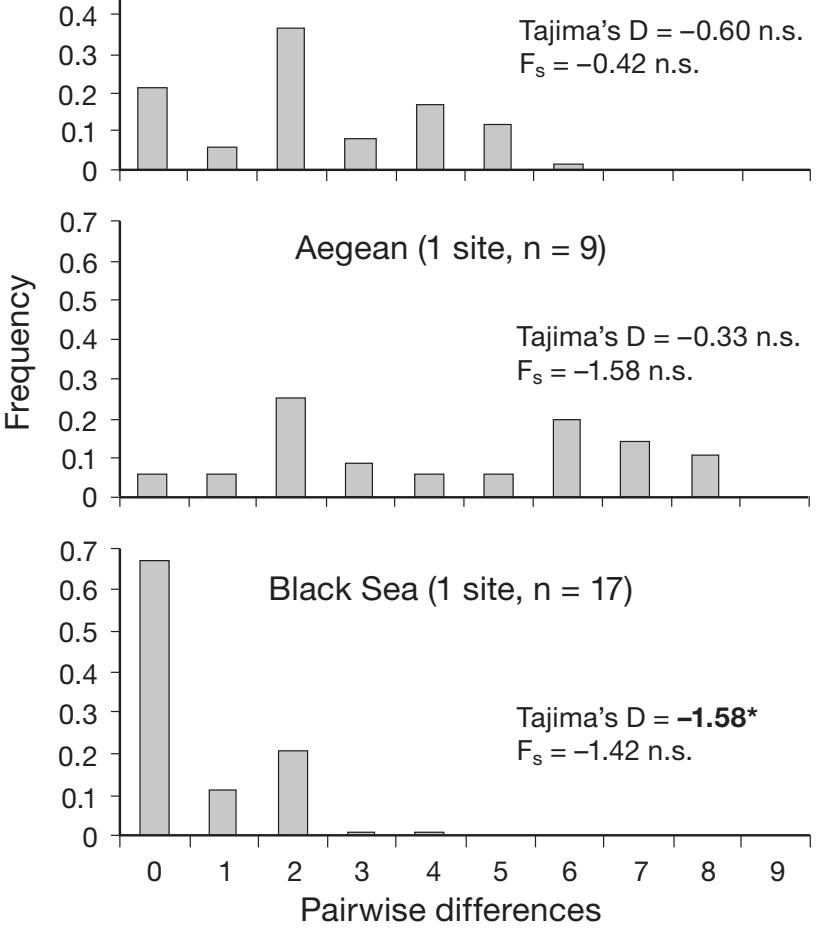

Fig. 2. Calanus helgolandicus and C. euxinus. Mismatch distributions of pairwise sequence differences for $C$. helgolandicus and $C$. euxinus for each phylogeographic group (see Fig. 1 and text). Results from the Tajima's D and Fu's $F_{s}$ neutrality tests are indicated with significant values in bold type: ${ }^{*} p<0.05$, ${ }^{* *} \mathrm{p}<0.01,{ }^{* * *} \mathrm{p}<0.001$ 


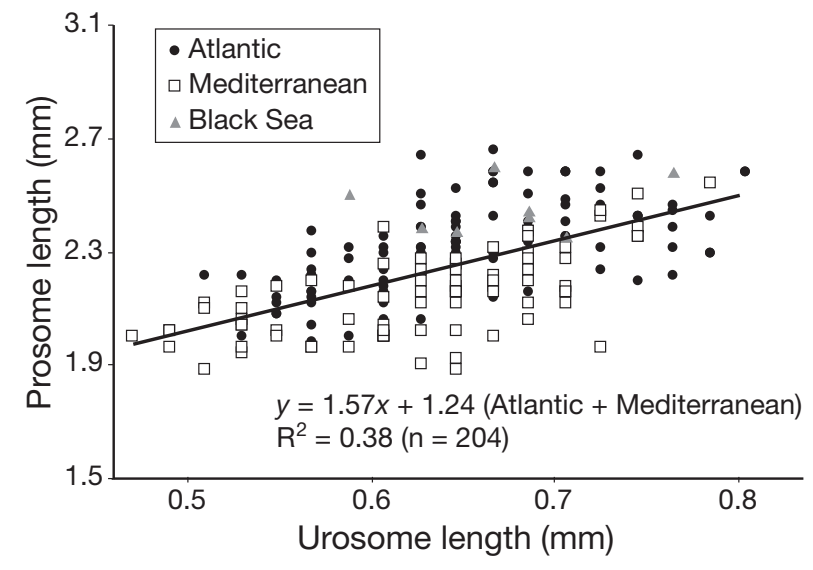

Fig. 3. Calanus helgolandicus and C. euxinus. Prosome length plotted against urosome length for $C$. helgolandicus (Atlantic and Mediterranean) and C. euxinus females (Black Sea). Prosome and urosome lengths were significantly positively related for each of the 7 phylogeographic groups except for the Black Sea. All Atlantic and Mediterranean samples were pooled because slopes and origins did not significantly differ between groups resulting in a single significant regression

latitudinal variation in the NE Atlantic since we observed a weak cline in prosome/urosome ratios. The fifth barrier separates the Aegean sample, which contained the smallest copepods. SST differed most strongly in the E Mediterranean (Fig. 4C), separating the Black Sea (first barrier) and the Adriatic Sea (second barrier) from the Aegean Sea similar to the steepest 2 morphometric clines. Additionally, the third and fifth SST barriers were congruent with morphometric barriers ( 3 and 5, respectively).

\section{DISCUSSION}

\section{Barriers in the pelagic}

In agreement with previous phylogeographic studies on the Calanus helgolandicus/C. euxinus species pair (Papadopoulos et al. 2005, Unal et al. 2006) we found highly significant genetic structuring of populations separated in different European basins. In the present study, however, we also uncovered significant spatial genetic structuring at the within-basin scale and obtained a better resolution of the geographic locations of barriers. In total, we found 7 phylogeographic groups: Fjords, Oceanic Inflow, NE Atlantic/Tyrrhenian, Adriatic Sea, Mljet Island, Aegean Sea and Black Sea. This high degree of genetic structuring suggests limited dispersal between as well as within basins which is remarkable given the fact that these copepods are holoplanktonic. The $16 \mathrm{~S}$ is generally assumed to be a conserved mitochondrial gene (Simon et al. 1994); however, in our study we found comparable rates of
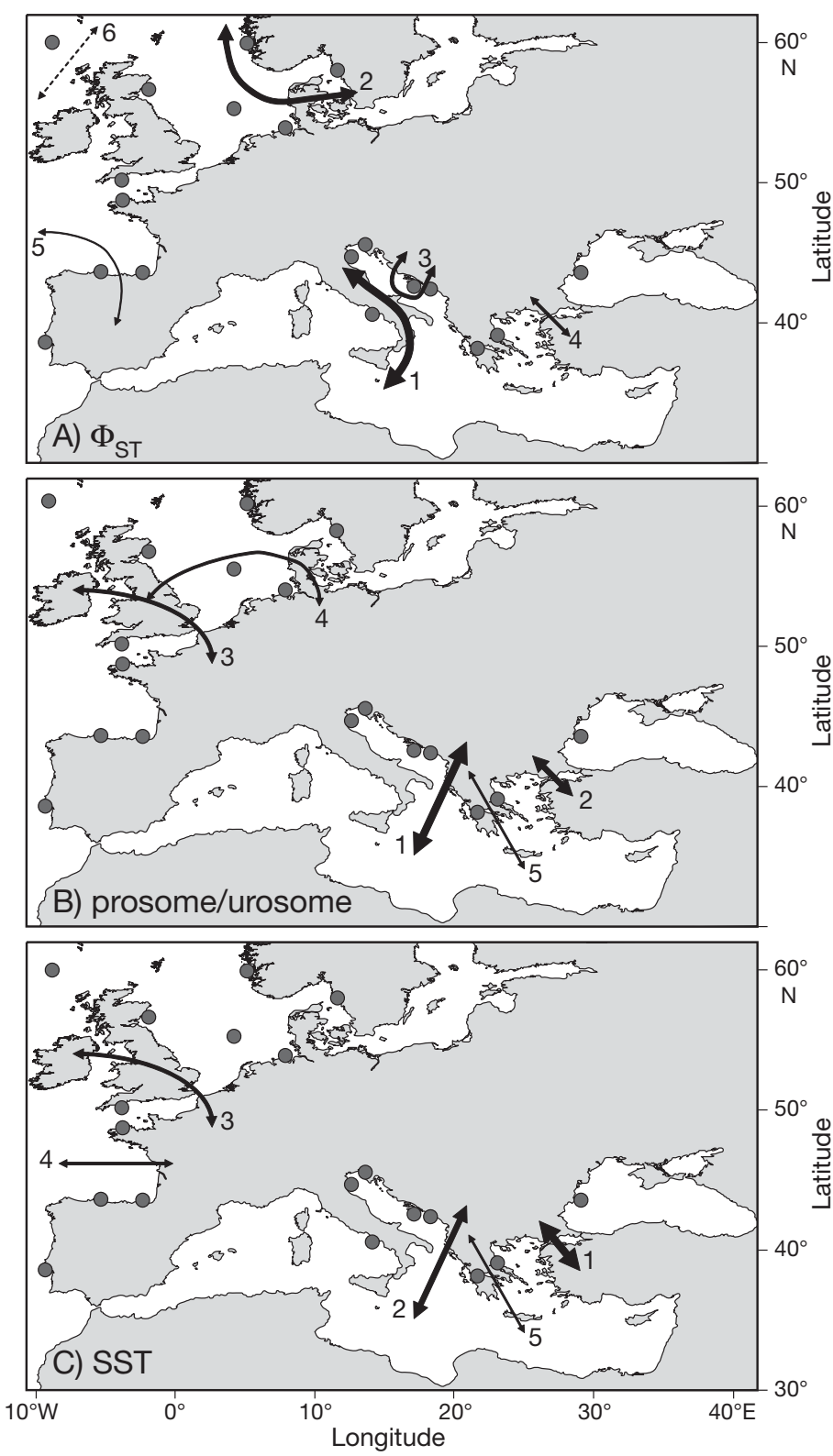

Fig. 4. Calanus helgolandicus and C. euxinus. Location of abrupt changes (barriers) in the (A) genetic $\left(\Phi_{\mathrm{ST}}\right)$ and $(\mathrm{B})$ morphometric (prosome/urosome length) composition of C. helgolandicus and C. euxinus samples, as well as (C) environmental barriers based on composite June and December SSTs. Thickness of barriers and numbers next to barriers indicate importance in decreasing order (see text for further explanations)

divergence between Atlantic, Adriatic, and Black Sea populations for $16 \mathrm{~S}$ as for COI (average ratio of between-group comparisons for COI/16S is 1.01, see Papadopoulos et al. 2005). Similar to previous genetic studies of marine copepods we also found highly skewed haplotype distributions and rather low estimates of genetic diversity (e.g. Bucklin \& Wiebe 1998, Bucklin et al. 2000a). A general limitation of this study 
is that genetic inferences are based on a single mitochondrial marker, which has a large stochasticity associated with it (Edwards \& Beerli 2000) and may not be neutrally or clock-like evolving (Ballard \& Whitlock 2004, Galtier et al. 2009). Adding information of multiple (nuclear) loci would result in more precise estimates and may allow neutral and selective effects to be disentangled. Keeping these general limitations in mind, 16S nevertheless provided sufficient amounts of genetic variation to reveal present-day barriers to gene flow as well as signatures of past demographic events.

The most important genetic barrier in the Calanus helgolandicus/C. euxinus distribution range separates $\mathrm{W}$ and E Mediterranean populations. Gene flow between these populations is absent or severely limited because communication can probably only occur through the narrow Strait of Messina (3 $\mathrm{km}$ wide, $<200 \mathrm{~m}$ deep) since the much wider Siculo-Tunisian Strait (160 km wide, $400 \mathrm{~m}$ deep) is located to the south of the species distribution range (Fleminger \& Hulsemann 1987). Several other marine species show genetic differentiation between $\mathrm{W}$ and $\mathrm{E}$ Mediterranean basins (e.g. Bahri-Sfar et al. 2000, Sala-Bozano et al. 2009), but the exact locations of barriers are usually unknown because of insufficient geographic sampling and may actually differ depending on the species biology.

NE Atlantic and W Mediterranean (Tyrrhenian) populations are not genetically differentiated based on our $16 \mathrm{~S}$ data even though the Strait of Gibraltar and the Almeria-Oran Front (AOF) are considered important phylogeographic barriers in many marine species (reviewed in Patarnello et al. 2007). Keeping in mind our limited sampling of the $\mathrm{W}$ Mediterranean (single Tyrrhenian sample, 12 individuals) there could be 2 explanations for this lack of structuring. (1) The NE Atlantic and Tyrrhenian Calanus helgolandicus populations are presently connected by high levels of dispersal. For instance, there is some evidence of transport of diapausing copepods across the Gibraltar Strait/AOF (Stöhr et al. 1996). (2) The populations are not or hardly connected, but our genetic data failed to reject homogeneity. There could be several explanations for this. Populations may not yet have reached mutationdrift equilibrium, which is plausible for extremely large zooplankton populations. Another possibility is that our genetic marker is not sensitive enough to reject homogeneity. However, it is difficult to explain that we found significant population structuring for other Calanus populations with the same genetic marker and similar sampling intensity. Another possibility is that a recent population bottleneck erased historical population structure and too little time has passed to allow for the accumulation of new genetic differences between NE Atlantic and Tyrrhenian populations.
The sharp genetic barrier separating W and E Mediterranean populations of Calanus helgolandicus is not congruent with the main morphometric barriers (prosome/urosome length) that separate Adriatic and Black Sea (C. euxinus) populations from Ionian and Aegean populations. Morphometric barriers reflect to a large extent SST barriers (Fig. 4). In terms of environmental conditions (0 to $500 \mathrm{~m}$ depth layer) during seasons when $C$. helgolandicus prevails, the Black Sea and E Mediterranean are at opposite ends of the spectrum, with the warm $\left(14\right.$ to $16^{\circ} \mathrm{C}$ ) and saline (38.8 to $38.9 \mathrm{psu}$ ) E Mediterranean waters to the west, and the cool ( 7.6 to $14^{\circ} \mathrm{C}$ ) and brackish (18 to $22 \mathrm{psu}$ ) Black Sea to the east (Fleminger \& Hulsemann 1987). There are also important ecological, behavioural and metabolic differences between the Black Sea C. euxinus and Mediterranean C. helgolandicus (reviewed in Fleminger \& Hulsemann 1987, Unal et al. 2006). This suggests that selection probably plays an important role in keeping these populations apart. Even though E Mediterranean and Black Sea populations share haplotypes there is probably hardly any contemporary gene flow between these basins because of the narrow connection through the straits of the Dardanelles, Sea of Marmara and the Bosphorus ( $3 \mathrm{~km}$ wide, $<200 \mathrm{~m}$ deep), which results in a thousand times lower flow than through the Strait of Gibraltar (Sverdrup et al. 1942). Furthermore, the communication is essentially one way, from the Black Sea to the E Mediterranean, as the more saline E Mediterranean waters immediately sink into the deep anoxic waters of the Black Sea. We found average uncorrected sequence divergence of $16 \mathrm{~S}$ between $C$. euxinus and $C$. helgolandicus of $0.39 \%$, which is similar to estimates based on COI and the cytochrome $b$ gene (CYTB) sequences (0.2 to $0.6 \%$, Papadopoulos et al. 2005, Unal et al. 2006). These values are within the range typically observed for conspecific calanoid copepod populations (e.g. Bucklin et al. 1999, 2003).

An interesting finding of this study is the genetic isolation of peripheral populations, in particular the 2 fjord populations and the marine lake population of Mljet Island. It is possible that fjord populations are connected by the Norwegian Coastal current that flows northwards from the Baltic Sea to the Norwegian Sea along the coast. The warmer and more saline waters of the Atlantic Ocean flow in the opposite direction entering the northern North Sea and create a front (Otto et al. 1990). This front may prevent mixing of fjord and NE Atlantic populations. Similar haplotype frequencies for 4 to 5 different Norwegian fjords were also reported by Bucklin et al. (2000a) for Calanus helgolandicus and C. finmarchicus, but not for Acartia clausi. Bucklin et al. (2000a) concluded that Calanus spp. fjord populations represented drifting populations that may be replaced periodically, whereas A. clausi 
populations were long-term residents in the fjords. An alternative explanation is that fjord populations are not connected by gene flow but share a recent common ancestor, and too little time has passed for genetic differences to have accumulated between fjord populations. Fjords are very young habitats and the fact that fjord populations of $C$. helgolandicus are characterized by high frequencies of the ancestral haplotype 5 support this explanation. The marine lake population of Mljet is also genetically isolated but shows a different picture. It contains a mixture of haplotypes including the ancestral H5, E Mediterranean haplotypes, and a high proportion of 2 related unique haplotypes (H30 and H31). This mixing of genetic lineages resulted in a higher estimate of genetic diversity than observed in the fjord populations even though this lake is also a young habitat (formed 4000 to $7000 \mathrm{yr}$ ago, Schmidt 1993, Benović et al. 2000). Ecologically and genetically differentiated assemblages in the Mljet lakes were also found for the moon jelly Aurelia sp. (Benović et al. 2000, Schroth et al. 2002) and the planktonic chaetognath Sagitta setosa (K. Peijnenburg \& M. Batistic unpubl. data). Strong stratification in summer differentiates the lakes, which are moderately eutrophic, from the oligotrophic surrounding $S$ Adriatic and may result in the isolation of deeper layers (20 to $45 \mathrm{~m}$ ) that have constantly lower temperatures (Benović et al. 2000).

The W Bay of Biscay (Gijón sample) was genetically differentiated from NE Atlantic samples but not from Faroe and Lisbon samples. There is a fluctuating front between the general oceanic circulation ( $\mathrm{N}$ Atlantic Central Water) and the slope current (Iberian Poleward Current) in the NW Iberian peninsula, which may be a strong hydrographic barrier isolating the $\mathrm{W}$ Bay of Biscay from the east and the north (Koutsikopoulos \& Le Cann 1996). Furthermore, Bonnet et al. (2005) reported a mismatch in the reproductive cycles of Calanus helgolandicus females from the SW Bay of Biscay and Roscoff (NE Atlantic) populations lending further support to the presence of a significant barrier in this region. Oceanic Inflow samples were characterized by a large proportion of the $\mathrm{H} 2$ haplotype, which is at least 4 mutational steps away from the most common haplotype in the NE Atlantic. It may be that the $\mathrm{H} 2$ haplotype is more abundant in the mid- or W Atlantic and is transported to the NE Atlantic by the Gulf Stream. To test this, samples would be necessary from the more western part of the $C$. helgolandicus distributional range.

\section{Biogeographic history}

Many studies on both terrestrial (e.g. Hewitt 2004) and marine (e.g. Patarnello et al. 2007) faunas have shown that the majority of contemporary genetic diversity in populations originated during the Pleistocene (1.8 million to 12000 yr ago). Even though most studies are based on a single mitochondrial marker and estimates of population divergence times should be interpreted with caution, the congruence across many unrelated species suggests that climatic oscillations during the Pleistocene had a major impact on species distribution patterns and demographies. Hence, intraspecific genetic variation cannot be interpreted without reference to the biogeographical past. Calanus helgolandicus and C. euxinus are considered cold water or 'boreal' elements in the Mediterranean and Black Sea faunas (e.g. Bianchi \& Morri 2000). In the Atlantic Ocean, $C$. helgolandicus is considere $\mathrm{d}$ to be an indicator of more temperate waters $\left(11.4\right.$ to $\left.16.1^{\circ} \mathrm{C}\right)$ than is C. finmarchicus $\left(6.0\right.$ to $10.6^{\circ} \mathrm{C}$, Helaouët \& Beaugrand 2007). It is also more typical of coastal areas ( 0 to $500 \mathrm{~m}$ ) compared with C. finmarchicus, and is thus considered a pseudo-oceanic or distant neritic species (Bonnet et al. 2005, Helaouët \& Beaugrand 2007). C. helgolandicus and $C$. euxinus occur where salinities are 35.7 to 38.9 psu and 18 to 22 psu (Fleminger \& Hulsemann 1987), respectively, and are thus dependent on marine conditions and ocean currents for their survival and dispersal.

The dynamic geological and climatic history of the Atlantic Ocean, Mediterranean Sea and Black Sea (reviewed in Patarnello et al. 2007 and Luttikhuizen et al. 2008) have left significant genetic signatures in Calanus helgolandicus and $C$. euxinus populations (Fig. 2). We found the highest levels of genetic diversity in the Mediterranean basin (Aegean Sea), which may be explained by a relatively long uninterrupted marine history of up to 5.3 million yr in this basin following the Messinian Salinity Crisis. By contrast, the North Atlantic Ocean and Black Sea regions were greatly affected by the Pleistocene ice ages when temperatures and sea levels fell, resulting in sea ice conditions as far south as the Iberian Peninsula during the Last Glacial Maximum (LGM, 18000 yr ago) in the Atlantic Ocean, and freshwater to brackish conditions as recent as $\sim 7000 \mathrm{yr}$ ago in the Black Sea. High levels of diversity may also be explained by higher temperatures in the Mediterranean Sea. For example, latitudinal diversity gradients in marine bacteria and copepods were largely explained by temperature (Fuhrman et al. 2008, Rombouts et al. 2009). Other studies with similar geographic sampling have also reported highest levels of genetic diversity in Mediterranean populations, e.g. for shrimp (Luttikhuizen et al. 2008) and chaetognaths (Peijnenburg et al. 2004). However, for these species W Mediterranean populations had highest levels of diversity and were significantly differentiated from 
Atlantic populations. Conversely, our W Mediterranean sample of $C$. helgolandicus was not significantly differentiated from Atlantic populations. Furthermore, NE Atlantic/Tyrrhenian sequences produced a star-like genealogy (Fig. 1b) and a typically L-shaped mismatch distribution, suggestive of a recent population bottleneck followed by expansion and/or selective sweep. We hypothesize that the most probable explanation for these observations is that the $\mathrm{W}$ Mediterranean was recently (re-)colonised from the Atlantic Ocean. However, more data are necessary to substantiate this hypothesis.

High levels of genetic diversity and multimodal mismatch distributions for the Oceanic Inflow, Mljet and Aegean populations are suggestive of more stable population sizes and/or mixing of divergent haplotypes in these areas. It may be that there were geographically separate refugia in the Atlantic and E Mediterranean basins where Calanus helgolandicus populations retracted and survived during glacial maxima. Pinpointing the exact locations of such refugia, however, would require much more geographic sampling and may remain elusive for such highly mobile populations as zooplankton.

Our results differ strikingly from a recent phylogeographic analysis of the congener Calanus finmarchicus sampled across the North Atlantic Ocean (Provan et al. 2009, but see Bucklin \& Wiebe 1998, Bucklin et al. $2000 \mathrm{~b}$ for a different result). Provan et al. (2009) concluded that $C$. finmarchicus is characterised by high levels of dispersal and has maintained a stable effective population size throughout Pleistocene climate changes. By contrast, C. helgolandicus/C. euxinus populations show strong genetic structuring even on small spatial scales and have been vulnerable to past climatic fluctuations as shown by strikingly different genetic signatures for phylogeographic groups. Furthermore, whereas $C$. finmarchicus probably persisted through the LGM as a single, continuous population (probably located in the NE Atlantic Ocean to the SW of the British Isles, Provan et al. 2009), C. helgolandicus probably survived in geographically separate refugia located in the Atlantic Ocean and E Mediterranean Sea because of the presence of distinct evolutionary lineages in both basins. If we assume similar evolutionary rates and comparable levels of selection on both species' mitochondrial DNA, the differences could be explained by the fact that distant neritic species ( $C$. helgolandicus) may be more vulnerable to climateinduced range shifts and compressions than are the more widely distributed oceanic species (C. finmarchicus). Similarly contrasting results were found for intraspecific mitochondrial DNA variation between a neritic and oceanic chaetognath, Sagitta setosa and $S$. elegans, respectively (Peijnenburg et al. 2005).
Dramatic biogeographical shifts have been documented for copepod assemblages associated with recent climate warming (Beaugrand et al. 2002, Hays et al. 2005, Conversi et al. 2009). For instance, in the Gulf of Trieste (N Adriatic Sea), ecosystem-wide changes are reported that include the increase of species with more southern distributions and a decline and/or changes in phenology of cold-water species such as Pseudocalanus elongatus and Calanus helgolandicus (Conversi et al. 2009). The response of copepods to climate change will be of crucial importance because of their central roles in marine food webs. In the NE Atlantic Ocean, C. helgolandicus will probably continue to expand its distribution northwards at the expense of $C$. finmarchicus, even though the latter species has a wider ecological tolerance (Helaouët \& Beaugrand 2007). This may result in the homogenization of the subtle population structure of Atlantic $C$. helgolandicus populations. In the Mediterranean and Black Sea basins, C. helgolandicus/C. euxinus populations may be particularly vulnerable to climate warming for several reasons. (1) Because the species are cold stenotherms, they are predicted to be gradually replaced by more thermotolerant species. (2) It will be impossible for species already trapped in the northernmost, coldest parts to migrate northwards. (3) The Mediterranean and Black seas are among the most impacted seas in the world, and climate change tends to interact synergistically with other disturbances (e.g. Oguz \& Gilbert 2007, Lejeusne et al. 2010). (4) Because we found ample evidence of population structuring and signs of local adaptation, it may not be possible for populations to simply 'track' changes in their habitat. We thus conclude that $C$. helgolandicus and $C$. euxinus are important species to monitor both ecologically as well as genetically.

Acknowledgements. We are indebted to A. Albaina, J. Cabal, K. Cook, R. Diekman, A. Dos Santos, E. Gaard, S. H. Jónasdóttir, L. Kamburska, D. Lučić, M. G. Mazzocchi, J. C. Nejstgaard, S. Poulet, A. Ramfos, P. Thor and V. Tirelli for supplying Calanus helgolandicus/C. euxinus specimens. We thank P. Pickerill for sequencing the samples, D. Conway for his help in sorting and identifying C. helgolandicus, and L. Blanco-Bercial, A. Bucklin, S. Mariani, P. Luttikhuizen, S. Menken and several anonymous referees for comments on earlier drafts of this manuscript. Completion of this work was funded by the European Social Fund (I3P-CSIC Programme contract to L.Y.) and The Netherlands Organisation for Scientific Research (NWOVENI 863.08.024 to K.P.). This work is a contribution to the PML Core Strategic Research Programme (UK).

\section{LITERATURE CITED}

Andersen V, Gubanova A, Nival P, Ruellet T (2001) Zooplankton community during the transition from spring bloom to oligotrophy in the open NW Mediterranean and effects of 
wind events. 2. Vertical distributions and migrations. J Plankton Res 23:243-261

Angel MV (1979) Zoogeography of the Atlantic Ocean. In: van der Spoel S, Pierrot-Bults AC (eds) Zoogeography and diversity of plankton. Bunge, Utrecht, p 168-190

> Angel MV (1993) Biodiversity of the pelagic ocean. Conserv Biol 7:760-772

Bagoeien E, Kaartvedt S, Oeveraes S (2001) Seasonal vertical migrations of Calanus spp. in Oslofjorden. Sarsia 85: 299-311

Bahri-Sfar L, Lemaire C, Ben Hassine OK, Bonhomme F (2000) Fragmentation of sea bass populations in the western and eastern Mediterranean as revealed by microsatellite polymorphism. Proc R Soc Lond B Biol Sci 267:929-935

Ballard JWO, Whitlock MC (2004) The incomplete natural history of mitochondria. Mol Ecol 13:729-744

Beaugrand G, Reid PC, Ibañez F, Lindley JA, Edwards M (2002) Reorganization of North Atlantic marine copepod biodiversity and climate. Science 296:1692-1694

Benović A, Lučić D, Onofri V, Perrada M, Carić M, Jasprica N, Bobanović-Ćolić S (2000) Ecological characteristics of the Mljet Island seawater lakes (South Adriatic Sea) with special reference to their resident populations of medusae. Sci Mar 64:197-206

Bianchi CN, Morri C (2000) Marine biodiversity of the Mediterranean Sea: situation, problems and prospects for future research. Mar Pollut Bull 40:367-376

Bonnet D, Richardson A, Harris R, Hirst A and others (2005) An overview of Calanus helgolandicus ecology in European waters. Prog Oceanogr 65:1-53

Bucklin A, Wiebe P (1998) Low mitochondrial diversity and small effective population sizes of the copepods Calanus finmarchicus and Nanocalanus minor: possible impact of climatic variation during recent glaciation. J Hered 89: 383-392

Bucklin A, Guarnieri M, Hill RS, Bentley AM, Kaartvedt S (1999) Taxonomic and systematic assessment of planktonic copepods using mitochondrial COI sequence variation and competitive, species-specific PCR. Hydrobiologia 401:239-254

Bucklin A, Kaartvedt S, Guarnieri M, Goswami U (2000a) Population genetics of drifting (Calanus spp.) and resident (Acartia clausi) plankton in Norwegian fjords. J Plankton Res 22:1237-1251

Bucklin A, Astthorsson OS, Gislason A, Allen LD, Smolenack SB, Wiebe PH (2000b) Population genetic variation of Calanus finmarchicus in Icelandic waters: preliminary evidence of genetic differences between Atlantic and Arctic populations. ICES J Mar Sci 57:1592-1604

Bucklin A, Frost BW, Bradford-Grieve J, Allen LD, Copley NJ (2003) Molecular systematic and phylogenetic assessment of 34 calanoid copepod species of the Calanidae and Clausocalanidae. Mar Biol 142:333-343

Clarke KR, Warwick RM (1994) Change in marine communities: an approach to statistical analysis and interpretation. Natural Environment Research Council Publication, Swindon

Conversi A, Peluso T, Fonda-Umani S (2009) Gulf of Trieste: a changing ecosystem. J Geophys Res 114:C03S90

De Vargas C, Norris R, Zaninetti L, Gibb SW, Pawlowski J (1999) Molecular evidence of cryptic speciation in planktonic foraminifers and their relation to oceanic provinces. Proc Natl Acad Sci USA 96:2864-2868

$>$ Edwards SV, Beerli P (2000) Perspective: gene divergence, population divergence, and the variance in coalescence time in phylogeographic studies. Evolution 54:1839-1854

Excoffier L, Laval G, Schneider S (2005) Arlequin (version
3.0): an integrated software package for population genetics data analysis. Evol Bioinform Online 1:47-50

Fleminger A, Hulsemann K (1987) Geographical variation in Calanus helgolandicus s.l. (Copepoda, Calanoida) and evidence of recent speciation of the Black Sea population. Biol Oceanogr 5:43-81

Fu YX (1997) Statistical tests of neutrality against population growth, hitchhiking and background selection. Genetics 147:915-925

Fuhrman JA, Steele JA, Hewson I, Schwalbach MS, Brown MV, Green JL, Brown JH (2008) A latitudinal diversity gradient in planktonic marine bacteria. Proc Natl Acad Sci USA 105:7774-7778

Furnestin ML (1979). Aspects of the zoogeography of the Mediterranean plankton. In: van der Spoel S, Pierrot-Bults AC (eds) Zoogeography and diversity of plankton. Bunge, Utrecht, p 191-253

Galarza JA, Carreras-Carbonell J, Macpherson E, Pascual M, Roques S, Turnere GF, Rico C (2009) The influence of oceanographic fronts and early-life-history traits on connectivity among littoral fish species. Proc Natl Acad Sci USA 106:1473-1478

> Galtier N, Nabholz B, Glémin S, Hurst GDD (2009) Mitochondrial DNA as a marker of molecular diversity: a reappraisal. Mol Ecol 18:4541-4550

Gislason A, Astthorsson OS (2002) The food of Norwegian spring-spawning herring in the western Norwegian Sea in relation to the annual cycle of zooplankton. Sarsia 87: $236-247$

Goetze E (2003) Cryptic speciation on the high seas; global phylogenetics of the copepod family Eucalanidae. Proc R Soc B Biol Sci 270:2321-2331

Hays GC, Richardson AJ, Robinson C (2005) Climate change and plankton. Trends Ecol Evol 20:337-344

- Helaouët P, Beaugrand G (2007) Macroecology of Calanus finmarchicus and C. helgolandicus in the North Atlantic Ocean and adjacent seas. Mar Ecol Prog Ser 345:147-165

> Hewitt GM (2004) Genetic consequences of climatic oscillations in the Quaternary. Philos Trans R Soc Lond B Biol Sci 359:183-195

Koutsikopoulos C, Le Cann B (1996) Physical processes and hydrological structures related to the Bay of Biscay anchovy. Sci Mar 60:9-19

Ladoukakis ED, Saavedra C, Magouolas A, Zouros E (2002) Mitochondrial DNA variation in a species with two mitochondrial genomes: the case of Mytilus galloprovincialis from the Atlantic, the Mediterranean and the Black Sea. Mol Ecol 11:755-769

- Lejeusne C, Chevaldonné P, Pergent-Martini C, Boudou-

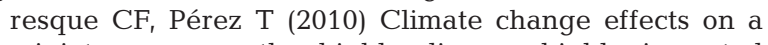
miniature ocean: the highly diverse, highly impacted Mediterranean Sea. Trends Ecol Evol 25:250-260

Lindeque PK, Harris RP, Jones MB, Smerdon GR (1999) Simple molecular method to distinguish the identity of Calanus species (Copepoda: Calanoida) at any developmental stage. Mar Biol 133:91-96

> Luttikhuizen PC, Campos J, van Bleijswijk J, Peijnenburg KTCA, van der Veer HW (2008) Phylogeography of the common shrimp, Crangon crangon (L.) across its distribution range. Mol Phylogenet Evol 46:1015-1030

> Magoulas A, Castilho R, Caetano S, Marcato S, Patarnello T (2006) Mitochondrial DNA reveals a mosaic pattern of phylogeographical structure in Atlantic and Mediterranean populations of anchovy (Engraulis encrasicolus). Mol Phylogenet Evol 39:734-746

> Manni F, Guérard E, Heyer E (2004) Geographic patterns of (genetic, morphologic, linguistic) variation: how barriers 
can be detected by 'Monmonier's algorithm'. Hum Biol 76: 173-190

Marshall DJ, Monro K, Bode M, Keough MJ, Swearer S (2010) Phenotype-environment mismatches reduce connectivity in the sea. Ecol Lett 13:128-140

Meyer-Harms B, Irigoien X, Head R, Harris R (1999) Selective feeding on natural phytoplankton by Calanus finmarchicus before, during, and after the 1997 spring bloom in the Norwegian Sea. Limnol Oceanogr 44:154-165

Nei M (1987) Molecular evolutionary genetics. Columbia University Press, New York, NY

Norris RD (2000) Pelagic species diversity, biogeography, and evolution. Paleobiology 26:236-258

$>$ Oguz T, Gilbert D (2007) Abrupt transitions of the top-down controlled Black Sea pelagic ecosystem during 19602000: evidence for regime-shifts under strong fishery exploitation and nutrient enrichment modulated by climate-induced variations. Deep-Sea Res I 54:220-242

Otto L, Zimmerman JTE, Furnes GK, Mork M, Saetre R, Becker G (1990) Review of the physical oceanography of the North Sea. Neth J Sea Res 26:161-238

Palumbi SR, Benzie J (1991) Large mitochondrial DNA differences among morphologically similar penaeid shrimp. Mol Mar Biol Biotechnol 1:27-34

Papadopoulos LN, Peijnenburg KTCA, Luttikhuizen PC (2005) Phylogeography of the calanoid copepods Calanus helgolandicus and C. euxinus suggests Pleistocene divergences between Atlantic, Mediterranean, and Black Sea populations. Mar Biol 147:1353-1365

Patarnello T, Volckaert FAMJ, Castilho R (2007) Pillars of Hercules: Is the Atlantic-Mediterranean transition a phylogeographic break? Mol Ecol 16:4426-4444

Peijnenburg KTCA, Breeuwer JAJ, Pierrot-Bults AC, Menken SBJ (2004) Phylogeography of the planktonic chaetognath Sagitta setosa reveals isolation in European seas. Evolution 58:1472-1487

Peijnenburg KTCA, van Haastrecht E, Fauvelot C (2005) Present-day genetic composition suggests contrasting demographic histories of two dominant chaetognaths of the North-East Atlantic, Sagitta elegans and S. setosa. Mar Biol 147:1279-1289

Pfenninger M, Posada D (2002) Phylogeographic history of the land snail Candidula unifasciata (Poiret 1801) (Helicellinae, Stylommatophora): fragmentation, corridor migration and secondary contact. Evolution 56:1776-1788

Provan J, Beatty GE, Keating SL, Maggs CA, Savidge G (2009) High dispersal potential has maintained long-term population stability in the North Atlantic copepod Calanus finmarchicus. Proc Biol Sci 276:301-307

Rogers AR, Harpending H (1992) Population growth makes waves in the distribution of pairwise genetic differences. Mol Biol Evol 9:552-569
Rombouts I, Beaugrand G, Ibanez F, Gasparini S, Chiba S, Legendre L (2009) Global latitudinal variations in marine copepod diversity and environmental factors. Proc Biol Sci 276:3053-3062

Rozas J, Sanchez-DelBarrio JC, Messeguer X, Rozas R (2003) DNASP, DNA polymorphism analyses by the coalescent and other methods. Bioinformatics 19:2496-2497

Sala-Bozano M, Ketmaier V, Mariani S (2009) Contrasting signals from multiple markers illuminate population connectivity in a marine fish. Mol Ecol 18:4811-4826

Schmidt R (1993) Environmental changes in two Adriatic coastal lakes in the time interval 7,500-5,000 B.P. (Atlantic) with special reference to the diatom succession of Cyclotella. Limnologica 23:47-58

Schroth W, Jarms G, Streit B, Schierwater B (2002) Speciation and phylogeography in the cosmopolitan marine moon jelly, Aurelia sp. BMC Evol Biol 2:1-10

Scotto di Carlo B, Ianora A (1983) Atlantis 2 cruise: copepod assemblages in deep Mediterranean waters. Rapp Proc Verb Reun CIESM 28:149-151

Simon C, Fratti F, Beckenbach A, Crespi B, Liu H, Flook P (1994) Evolution, weighting, and phylogenetic utility of mitochondrial gene sequences and a compilation of conserved polymerase chain reaction primers. Ann Entomol Soc Am 87:651-701

Stöhr S, Schulz K, John HC (1996) Population structure and reproduction of Calanus helgolandicus (Copepoda, Calanoida) along the Iberian and Moroccan slope. Helgol Mar Res 50:457-475

Sverdrup HV, Johnson MW, Fleming RH (1942) The oceans, their physics, chemistry and general biology. PrenticeHall, New York, NY

Swofford DL (1998) PAUP*: phylogenetic analysis using parsimony ( ${ }^{*}$ and other methods). Sinauer Associates, Sunderland, MA

Tajima F (1983) Evolutionary relationships of DNA sequences in finite populations. Genetics 105:597-601

Tajima F (1989) Statistical method for testing the neutral mutation hypothesis by DNA polymorphism. Genetics 123:585-595

- Unal E, Frost BW, Armbrust V, Kideys AE (2006) Phylogeography of Calanus helgolandicus and the Black Sea copepod Calanus euxinus, with notes on Pseudocalanus elongatus (Copepoda, Calanoida). Deep-Sea Res II 53:1961-1975

> Weikert H, Koppelmann R, Wiegratz S (2001) Evidence of episodic changes in deep-sea zooplankton abundance and composition in the Levantine Sea (Eastern Mediterranean). J Mar Syst 30:221-239

Williams R, Conway DVP (1988) Vertical distribution and seasonal numerical abundance of the Calanidae in oceanic waters to the south-west of the British Isles. Hydrobiologia 167-168:259-266 
Appendix 1. Additional genetic data for Calanus helgolandicus/C. euxinus

Table A1. Calanus helgolandicus and C. euxinus. Geographic distribution of 16S mitochondrial haplotypes (H) for both species. P indicates pool of unique haplotypes

\begin{tabular}{|c|c|c|c|c|c|c|c|c|c|c|c|c|c|c|c|c|c|c|}
\hline Sample & H1 & $\mathrm{H} 2$ & H3 & H5 & H13 & H16 & H17 & H19 & $\mathrm{H} 21$ & $\mathrm{H} 26$ & $\mathrm{H} 27$ & H31 & H34 & H38 & H41 & H42 & $\mathrm{P}$ & Total \\
\hline Raunefjord & 4 & & & 12 & & & & & & & & & & & & & 2 & 19 \\
\hline Gulmarfjord & 3 & & & 11 & & & 1 & & 1 & & & & & & & & 2 & 18 \\
\hline Faroe & 10 & 5 & & & & & & & & & & & & & 1 & & 0 & 16 \\
\hline Gijón & 10 & 7 & 1 & 1 & & & & & & & & & & & & & 3 & 22 \\
\hline Lisbon & 4 & & & & & & & & & & & & & & & & 0 & 4 \\
\hline Stonehaven & 11 & & & & & & & & & & 1 & & & & & & 1 & 13 \\
\hline Dogger Bank & 17 & 1 & 1 & & & & & & 1 & 1 & & & & & & & 2 & 23 \\
\hline Helgoland & 12 & & 1 & & & & & & & & & & & & & & 1 & 14 \\
\hline Plymouth & 45 & 2 & 1 & 3 & 2 & & & & & & 1 & & & & & & 5 & 59 \\
\hline Roscoff & 12 & 1 & & & & & & & & & & & & & & & 1 & 14 \\
\hline San Sebastián & 14 & & & & & & & & & 1 & 1 & & & & & & 0 & 16 \\
\hline Tyrrhenian & 8 & & & 1 & & & & & & & & & & & 1 & 2 & 0 & 12 \\
\hline N Adriatic & & & & 2 & & & & 8 & & & & & & 2 & & & 2 & 14 \\
\hline Trieste & 3 & & & 1 & & 3 & & 5 & & & & & & & & & 2 & 14 \\
\hline S Adriatic & & & & 1 & & 3 & & 5 & & & & & & & & & 2 & 11 \\
\hline Ionian & & & & 3 & & 1 & & 1 & & & & & & & & & 1 & 6 \\
\hline Mljet & & 1 & & 4 & & & & 2 & & & & 6 & & & & & 2 & 15 \\
\hline Aegean & & & & 2 & & & 1 & & & & & & 2 & & & & 4 & 9 \\
\hline Black Sea & & & & 14 & & 1 & & & & & & & & & & & 2 & 17 \\
\hline Total & 154 & 17 & 4 & 55 & 2 & 8 & 2 & 21 & 2 & 2 & 3 & 6 & 2 & 2 & 2 & 2 & 32 & 316 \\
\hline
\end{tabular}

Table A2. Calanus helgolandicus and C. euxinus. Average genetic p-distances (in percentage) between and within (on the diagonal in bold text) 7 phylogeographic groups of $C$. helgolandicus (Atlantic and Mediterranean) and C. euxinus (Black Sea)

\begin{tabular}{|lccccccc|}
\hline & $\mathrm{n}$ & $\begin{array}{c}\text { Fjords } \\
\text { inflow }\end{array}$ & $\begin{array}{c}\text { Oceanic } \\
\text { Tyrrhenian }\end{array}$ & NE Atlantic/ & Adriatic & Mljet & Aegean \\
\hline Fjords & 37 & $\mathbf{0 . 2 0}$ & & & & & \\
Oceanic Inflow & 38 & 0.48 & $\mathbf{0 . 5 3}$ & & & & \\
NE Atlantic/Tyrrhenian & 151 & 0.30 & 0.47 & $\mathbf{0 . 1 9}$ & & & \\
Adriatic & 39 & 0.50 & 0.81 & 0.64 & $\mathbf{0 . 3 9}$ & & $\mathbf{1 . 0 6}$ \\
Mljet & 15 & 0.52 & 0.82 & 0.69 & 0.66 & $\mathbf{0 . 5 7}$ & \\
Aegean & 9 & 0.73 & 0.95 & 0.85 & 0.95 & 1.01 & 0.75 \\
Black Sea & $\mathrm{n}$ & 0.20 & 0.53 & 0.37 & 0.42 & 0.45 & $\mathbf{0 . 1 4}$ \\
\hline
\end{tabular}

Editorial responsibility: Philippe Borsa, Montpellier, France
Submitted: July 14, 2010; Accepted: January 23, 2011 Proofs received from author(s): April 5, 2011 